\title{
Determination of the optimal battery capacity of a PEM fuel cell vehicle taking into account recuperation and supercapacitors
}

\author{
Swantje C. Konradt ${ }^{1} \cdot$ Hermann Rottengruber ${ }^{1}$
}

Received: 11 January 2021 / Accepted: 19 July 2021 / Published online: 4 August 2021

(c) The Author(s) 2021

\begin{abstract}
Proton exchange membrane (PEM) fuel cell vehicles require an electrical intermediate storage system to compensate for dynamic load requirements. That storage system uses a battery and has the task to increase tolerance to dynamic operation. In addition, energy can be recuperated and stored in supercapacitors to increase the fuel cell vehicle's efficiency. To determine the optimal battery capacity according to the recuperation potential and possible use of a supercapacitor, a reference vehicle with PEM fuel cell was transferred to the simulation environment Matlab/Simulink. The model is based on a cell model describing the electrochemical and physical interactions within the cell. It has been implemented in a complete vehicle model for the representation of a fuel cell vehicle. Various legal driving cycles, such as the WLTP ("Worldwide harmonized Light Vehicles Test Procedure"), were used for the calculations. A further step sets the optimal battery capacity depending on the dynamic of the fuel cell system. With this simulation model, dynamic requirements-for the fuel cell and the associated system components— can be determined in the future, scalable for each vehicle depending on the battery capacity and recuperation potential.
\end{abstract}

Keywords Fuel cell vehicle $\cdot$ Simulation $\cdot$ Proton exchange membrane fuel cell $\cdot$ Matlab $\cdot$ Simulink $\cdot$ Dynamic fuel cell model $\cdot$ Battery management $\cdot$ Recuperation $\cdot$ Supercapacitor

\section{Introduction}

Fuel cell electric vehicles (FCEV) are an alternative to battery electric vehicles (BEV). They combine the advantages of BEV and conventional internal combustion engine vehicles. FCEV have a long range with short refueling times and are locally emission-free. ([1], p. 90 et. seq.)

There are some challenges in the dimensioning and use of a PEM fuel cell in a vehicle. On one hand, this includes conditioning the fuel cell when the vehicle is switched on and off. This is due to the reduced cold start capability as well as the system behaviour during shutdown. In fact, there is no consideration of conditioning necessary during operation.

Swantje C. Konradt

swantje.konradt@ovgu.de

Hermann Rottengruber

hermann.rottengruber@ovgu.de

1 Institute of Mobile Systems (IMS), Professorship for Energy Conversion Systems for Mobile Applications, (EMA), OttoVon-Guericke University Magdeburg, Universitätsplatz 2, 39106 Magdeburg, Germany
On the other hand, there is a conflict between the service life and the dynamic operation of a fuel cell. This is because dynamic operation can lead to critical operating conditions, such as short-term over- or undersupply of the operating media. As a consequence of the resulting degradation mechanisms, the cells service life can be reduced. [2,3] To compensate for the dynamic operation, an electrical intermediate storage is used in FCEV as a buffer. When selecting a storage, however, various factors, such as capacity and type, must be considered. Various studies have focused on this question investigating the use of a battery as an intermediate storage system. This preliminary work has its focus, among other things, on component sizing or on the influence analysis of the fuel cells efficiency and service life as a function of battery and cell size (cf. [4-6, 8, 9]). Alternatively, a supercapacitor can be used as an intermediate storage (cf. [7-10]). This can increase the recuperation potential and thus the efficiency of the drive train. Another way to exploit the efficiency potential is to combine the energy storage battery and supercapacitor (cf. [11, 12]). This allows to combine the advantages of the two energy storage systems, a high 
energy density of the battery and a high current tolerance of the supercapacitor.

Different to previous investigations, this work also analyzes the influence of variable fuel cell dynamics on the design of the energy storage system. It additionally considers the various options, the sole use of a battery or of a supercapacitor as well as their combination. For this purpose, various operating strategies have been developed with the aim of minimizing the required battery capacity. Furthermore, the implemented scalability ensures the applicability of the generated vehicle model for different scenarios.

The dimensioning of an FCEV requires a holistic approach. Considering the overall system requires to take into account the interdependencies within the cell, the operating media management and the electric drive train. The generated model facilitates to determine the optimal battery capacity of a PEM fuel cell vehicle with consideration of the supercapacitor and recuperation depending on the varying system behaviour of the fuel cell.

\section{Vehicle system}

The simulation model includes a complete vehicle system consisting of the powertrain, the body work and the chassis, and is controlled by a driver in form of a PI controller. The powertrain is designed as a hybrid vehicle and can be customized according to the requirements (e.g., serial or parallel hybrid). The vehicle is based on the reference vehicle Mercedes Benz GLC F-Cell and was used for driving cycle calculation and energy flow analysis (Table 1).

\subsection{Fuel cell}

The fuel cell used is a polymer electrolyte membrane (PEM) fuel cell. The calculations are based on a Matlab model for describing electrochemical and physical interactions within the cell. Moreover, the fuel cell system consists of media management (hydrogen, oxygen, water). The cell operates in

Table 1 Characteristics of the reference vehicle [13]

\begin{tabular}{ll}
\hline Name/type & Value \\
\hline Vehicle & Mercedes Benz GLC F-Cell \\
Vehicle class & $\mathrm{J}(\mathrm{SUV})$ \\
Max. power PEM-FC & $75 \mathrm{~kW}$ \\
Power electric motor & $140 \mathrm{~kW}(314 \mathrm{Nm})$ \\
Reference battery capacity & $13.8 \mathrm{kWh}$ \\
Specific energy & $15 \mathrm{Wh} / \mathrm{kg}$ \\
Nominal voltage of the high-voltage & $360 \mathrm{~V}$ \\
$\quad$ system & \\
Transmission ratio of the differential & 9.08
\end{tabular}

an efficiency-optimal way in the partial load range, stationary, if possible. Mobile operation requires dynamic behaviour. [14]

The dynamic load behaviour of PEM fuel cells depends on various operating parameters. These include temperature, pressure, humidity, stoichiometry and the quantity of operating gases. Critical operating conditions during dynamic operation lead to a reduction in the electrochemically active surface of the catalyst along with an increase in material transport and cell resistance due to degradation. These conditions can result in long-term lifetime reductions. [2,3] The critical operations include short-term under- or oversupply with operating gases as well as deviations in operating limits. For example, in the case of a load step, the membrane may dry out, which leads to a decrease in the fuel cells' performance due to inhibited proton exchange through the membrane $[2,3] 2$. The assumed fuel cell has a maximum output of $75 \mathrm{~kW}$ and an operating optimum at approximately $38 \%$ of the peak power according to ([1], p. 115). The dynamic of the fuel cell was varied in the simulation to map the effect of the system behaviour on the required battery capacity.

1

\subsection{Battery system}

The battery is installed in the FCEV as an electrical intermediate storage device. As mentioned above, this is meant to reduce the dynamic demand on the fuel cell system. Additionally, current excess energy is stored with the help of the battery. This energy results from the PEM fuel cell or recuperation in the form of braking energy recovery. ([20], p. 110).

A high-performance lithium-ion battery is integrated in the simulation (Table 2). High-performance cells are charged according to the constant current method. The resulting cell voltage depends on its state-of-charge (SOC) and the current load, and defines the maximum possible charge or rather discharge power. The regular SOC is targeted between 30 and $80 \%$ to the batteries preserve lifetime. However, these boundaries could be exceeded to compensate the start or shut down of the fuel cell with less than the continuous

Table 2 Parameter of the battery ([15], p. 298)

\begin{tabular}{lll}
\hline Name/type & Value & Unit \\
\hline Max. charging current (cont.) & 3 & C-rate \\
Max. charging current (peak, $t<10 \mathrm{~s}$ ) & 5 & C-rate \\
Max. discharge current (cont.) & 12 & C-rate \\
Max. discharge current (peak, $t<10 \mathrm{~s}$ ) & 15 & C-rate \\
Nominal battery cell voltage & 3.6 & V \\
Number of cells & 100 & \\
\hline
\end{tabular}


Fig. 1 Charging and discharging curve of a high-performance lithium-ion-battery cell ([15], p. 300)

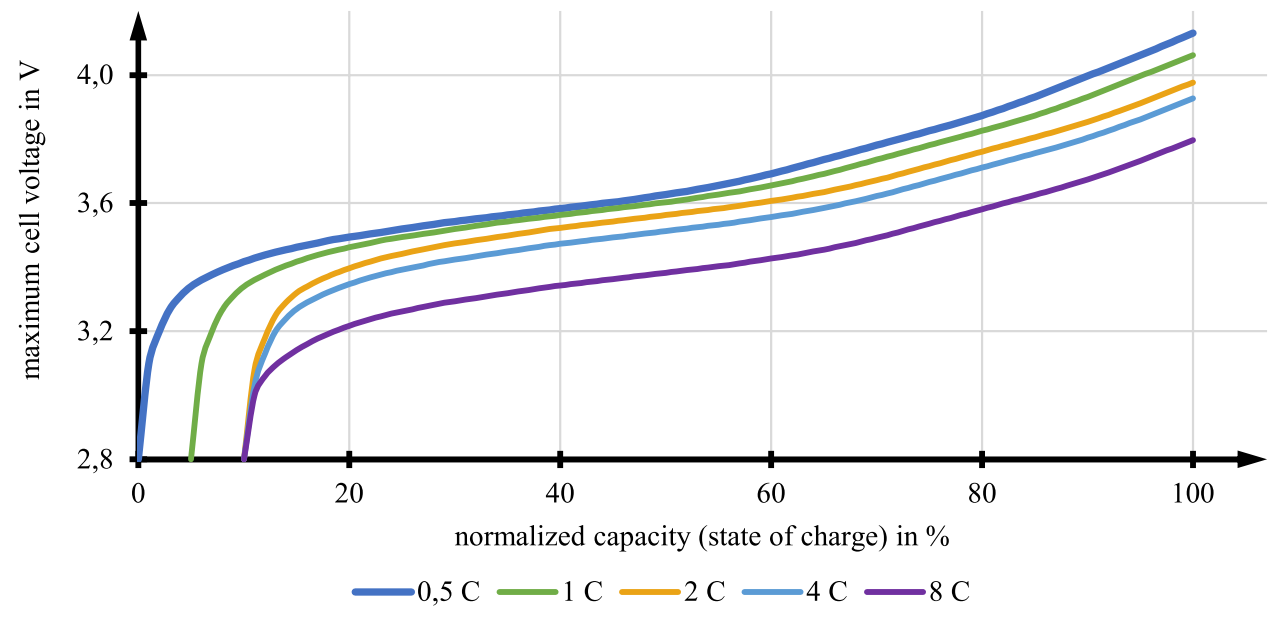

performance limits of 3 or $5 \mathrm{C}$, but not for regenerative braking or boosting reasons. The $\mathrm{C}$-rate is defined as the quotient of the battery current and the battery capacity. It serves to compare batteries with different capacities. Overcharging the cell, after the end-of-charge voltage of $4.2 \mathrm{~V}$ has been reached, is not possible and would rather decrease battery life. For this reason, a reduction of the maximum current according to the constant voltage charging method is not necessary ([15], p. 299 et. seq.).

In the context of the simulation, a battery with an ideal battery management system is assumed. It carries out the complete charge redistribution between the weakest cell (discharge) and the strongest cell (charge) through 'active bottom and top balancing'. The compensation losses are assumed to be $1.5 \mathrm{~W}$ per cell block ([19], p. 182 et. seq.).

The load-dependent charging or discharge characteristic of the battery cell voltage is shown in Fig. 1. The power electronic has the task to limit the batteries power. Depending on the operating case, energy has to be either emitted or supplied. The temperature dependence of the battery cell voltage is not considered, because the battery thermal management is not yet fully implemented in the vehicle model.

\subsection{Supercapacitor}

A supercapacitor describes an electrical component for storing electrical charge. This component consists of a so-called electrochemical double-layer capacitor which is a highly efficient storage with comparatively low internal resistance. The supercapacitor's task is to increase the efficiency of the drive train by storing recuperated energy and power generated by the FCEV. This reduces the strain of the high-performance battery ([18], p. 27 et. seq.).

For the simulation, a supercapacitor for automotive applications was selected that shows the parameters listed in the following table (Table 3) ([16], p. 242 et. seq.).
Table 3 Parameters of the supercapacitor [17]

\begin{tabular}{lll}
\hline Name/type & Value & Unit \\
\hline Nominal capacitance & 10 & $\mathrm{~F}$ \\
Capacitance tolerance & $+20 /-0$ & $\%$ \\
Rated voltage & 90 & $\mathrm{~V}$ \\
Absolute maximum voltage & 95 & $\mathrm{~V}$ \\
Resistance & 120 & $\mathrm{~m} \Omega$ \\
Maximum current (cont.) & 25 & $\mathrm{~A}$ \\
Maximum current (peak, $t<1 \mathrm{~s})$ & 230 & $\mathrm{~A}$ \\
Operating temperature range & $-40 /+65$ & ${ }^{\circ} \mathrm{C}$ \\
Gravimetric energy density & 1.4 & $\mathrm{Wh} / \mathrm{kg}$ \\
Available energy & 11.2 & $\mathrm{Wh}$ \\
Cycle life & 1.000 .000 & $\mathrm{Cycle}$ \\
\hline
\end{tabular}

\section{Operational strategy}

To design an optimal control for the vehicle system, an operating strategy for the overall system is necessary. Assumptions have been made regarding the battery, the supercapacitor and the fuel cell model for the regulation of recuperation capability. Especially, the charging and discharging performance of the battery and the supercapacitor during operation were considered. Two different processes need to be examined, the continuous and the peak mode. The continuous charging or unloading power describes the constant possible value for non-stop operation. The peak mode refers to a short-term overload 4 .

The vehicles' braking system feeds the recuperation function of the storage system, reflected in the recuperation performance (PR). This recuperation capability may exceed the consistently assumed power of the PEM fuel cell system.

The energy flows are combined with the help of the DC busbar, which is shown schematically in Fig. 2. The DC busbar records the operating states of the fuel cell, the battery, the supercapacitor, the electric motor and the auxiliary 
DC busbar

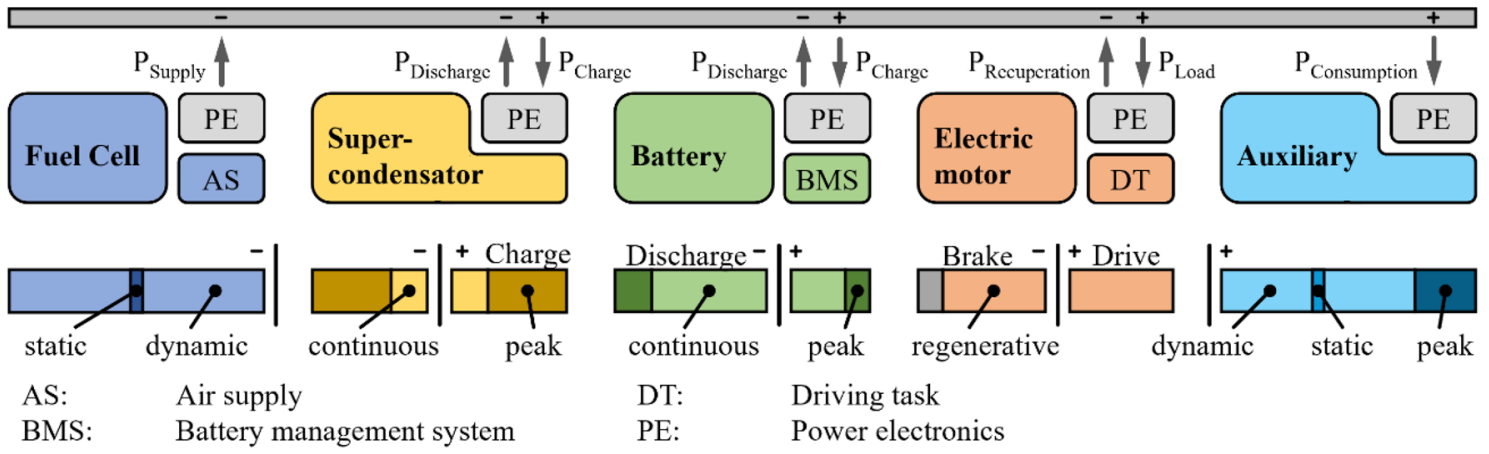

Fig. 2 Energy flows in the components of the power train

consumers. The various potentials of the components are converted by means of power electronics to a uniform voltage level, which is specified by the battery management system. The behaviour of these components is divided into continuous operation and peak performance. While the energy storage devices can both store and deliver, the fuel cell is only able to deliver energy. Meanwhile, auxiliary consumers only consume energy. The electric motor can be used for driving and recuperating. It is characterized by an adapted map of an asynchronous machine.

The DC busbar is followed by the operating strategy which regulates the power flows of the components of the electric drive train. The operating strategy was developed as a so-called 'causal' strategy. This is based on the use of

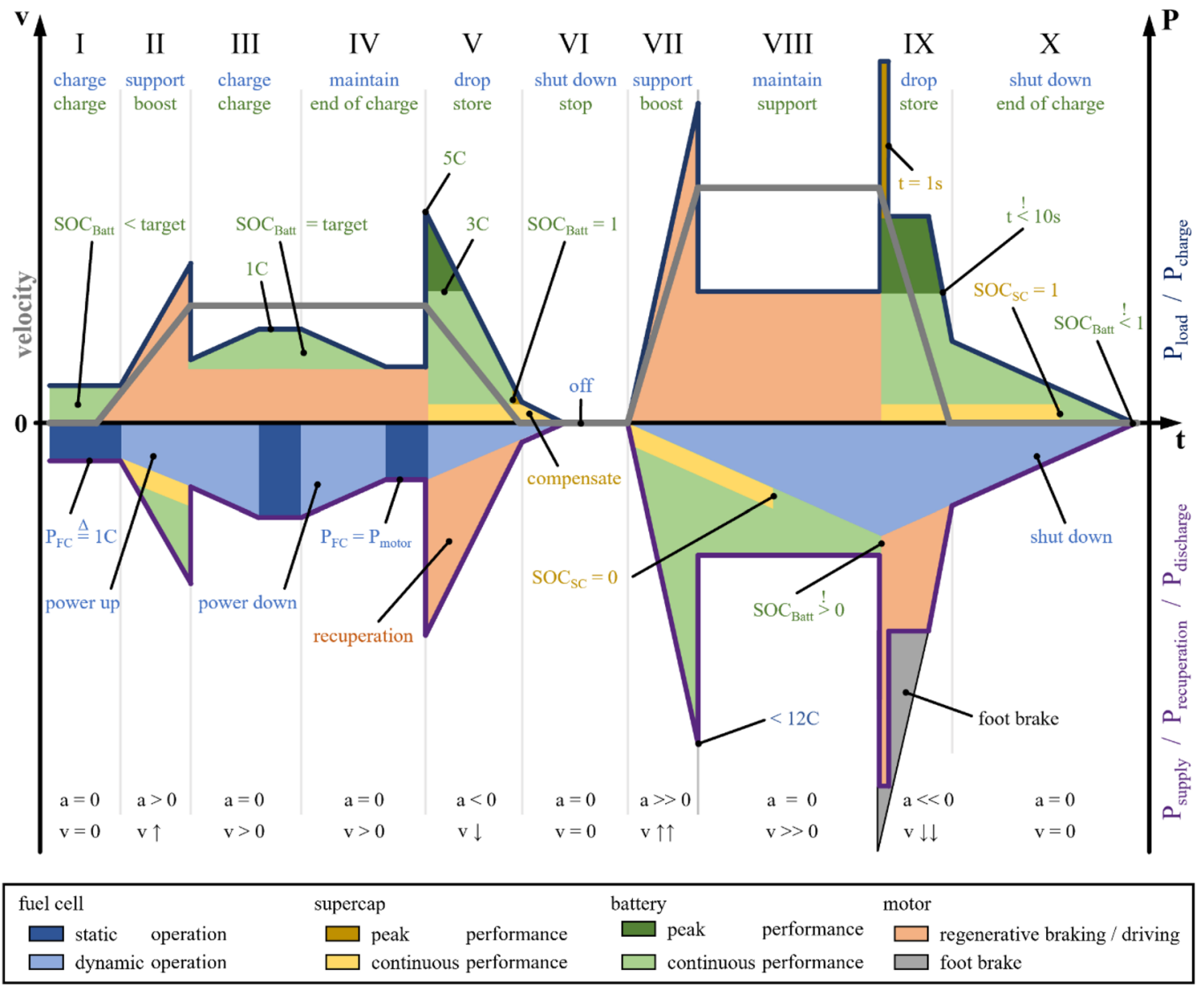

Fig. 3 Schematic power distribution of the vehicle system 
Table 4 Description of possible operation states shown in Fig. 3

\begin{tabular}{|c|c|c|c|c|}
\hline State & Vehicle & Fuel cell & Battery & Supercapacitor \\
\hline I & Standstill, charging & $\begin{array}{l}\text { Charge battery continuously with } \\
\text { preset power }\end{array}$ & Being charged & Not required \\
\hline II & Acceleration & $\begin{array}{l}\text { Power up with maximum or rather } \\
\text { needed dynamic gradient }\end{array}$ & $\begin{array}{l}\text { Stop charging and start to boost } \\
\text { motor }\end{array}$ & Support fuel cell and battery \\
\hline III & Driving charging & $\begin{array}{l}\text { Increase supply to sum of required } \\
\text { driving and charging power }\end{array}$ & Return charging & Not required \\
\hline IV & Driving, sustaining mode & $\begin{array}{l}\text { Decrease supply to demanded driv- } \\
\text { ing power }\end{array}$ & $\begin{array}{l}\text { Stop charging if preset state-of- } \\
\text { charge is reached }\end{array}$ & Not required \\
\hline V & regenerative braking & $\begin{array}{l}\text { Drop power with maximum or } \\
\text { rather needed dynamic gradient to } \\
\text { enhance recuperation potential }\end{array}$ & $\begin{array}{l}\text { Store regenerative braking power } \\
\text { with peak charging current }\left(5^{\circ} \mathrm{C}\right)\end{array}$ & $\begin{array}{l}\text { Support battery to improve recu- } \\
\text { peration capability }\end{array}$ \\
\hline VI & Vehicle stop & $\begin{array}{l}\text { Shut down because of non-existent } \\
\text { driving load and full battery }\end{array}$ & $\begin{array}{l}\text { Not able to compensate for too low } \\
\text { FC dynamic }\end{array}$ & $\begin{array}{l}\text { Store residual power due to full } \\
\text { battery }\end{array}$ \\
\hline VII & Acceleration & $\begin{array}{l}\text { Power up with maximum dynamic } \\
\text { gradient }\end{array}$ & $\begin{array}{l}\text { Boost motor with continuous } \\
\text { current }\end{array}$ & Support fuel cell and battery \\
\hline VIII & Driving & $\begin{array}{l}\text { Raise power with maximum and } \\
\text { accordingly needed dynamic }\end{array}$ & $\begin{array}{l}\text { Provide additional power as result } \\
\text { of minor fuel cell performance }\end{array}$ & Support battery until it is empty \\
\hline IX & Stop with friction brake & Drop power with maximum ascent & $\begin{array}{l}\text { Accumulate energy with maximum } \\
\text { capability }\end{array}$ & Buffer energy with peak effort \\
\hline $\mathrm{X}$ & Vehicle stop & Shut down because of zero load & $\begin{array}{l}\text { Compensate for fuel cell dynamic } \\
\text { potential }\end{array}$ & $\begin{array}{l}\text { Charged allowing for prospective } \\
\text { speedup }\end{array}$ \\
\hline
\end{tabular}

currently available vehicle data as input parameters. It is also designed as an optimal operating strategy with the aim to achieve minimum storage capacity with varying fuel cell dynamics. It was optimized for a dynamic use-case according to the boundary parameters of the components of the power train. In particular, the state-of-charge of the battery as well as the charging and discharging limits of the supercapacitor. Especially, the battery has an enormous influence on the design of the operating strategy.

The operating strategy was developed for three constellations of energy storage systems: for the solitary use of a battery or a supercapacitor and for the combination of the two energy storage systems, which can be seen in Fig. 3. The load requirement can be roughly divided into ten operating states (Table 4) ([16], p. 287 et. seq.).

\section{Simulation result}

To determine the optimal battery capacity of a PEM fuel cell vehicle taking into account recuperation and supercapacitor, calculations of different driving cycles were performed using the generated simulation model. In addition, the required dynamics of the fuel cell system were varied to select an optimal battery capacity.

The results are shown for the energy storage variants battery, battery and supercapacitor as well as a larger supercapacitor. They are presented as an example with the standardized driving cycle WLTP ("Worldwide harmonized Light Vehicles Test Procedure").

Figure 4 shows the required battery capacity of the fuel cell vehicle for the WLTP without using the supercapacitor depending on the dynamics of the fuel cell system. It can be seen that a lower battery capacity can be chosen as the dynamic increases. However, this influence stagnates from a dynamic of $5000 \mathrm{~W} / \mathrm{s}$, because the battery system contributes to the continuance of power distribution of the drivetrain and must not fall below a certain capacity. In addition, the figure shows that the efficiency of the fuel cell system, including media management, has a range between 57 and $50 \%$. It can be seen that the recuperation capacity is limited without the use of a supercapacitor with low battery capacities. The recuperation ability has an amount average $31.4 \%$. This is because with low storage capacities and high fuel cell dynamics, the battery is unable to absorb all recuperation energy. Based on these results, it can be stated that the battery capacity of the reference vehicle without the use of the supercapacitor is limited to $0.6 \mathrm{kWh}$.

Figure 5 shows that the battery's charging and discharging energy decreases overall with greater fuel cell dynamics. This is because the fuel cell can adapt to the required performance to fulfil the driving task. Additional energy storages to compensate for the dynamic limitation are therefore only required to a limited extent. The barely variable fuel cell efficiency results from the low load requirements of the WLTP compared to the installed fuel cell power. For this reason, 
Fig. 4 Simulation result of the WLTP without supercapacitor
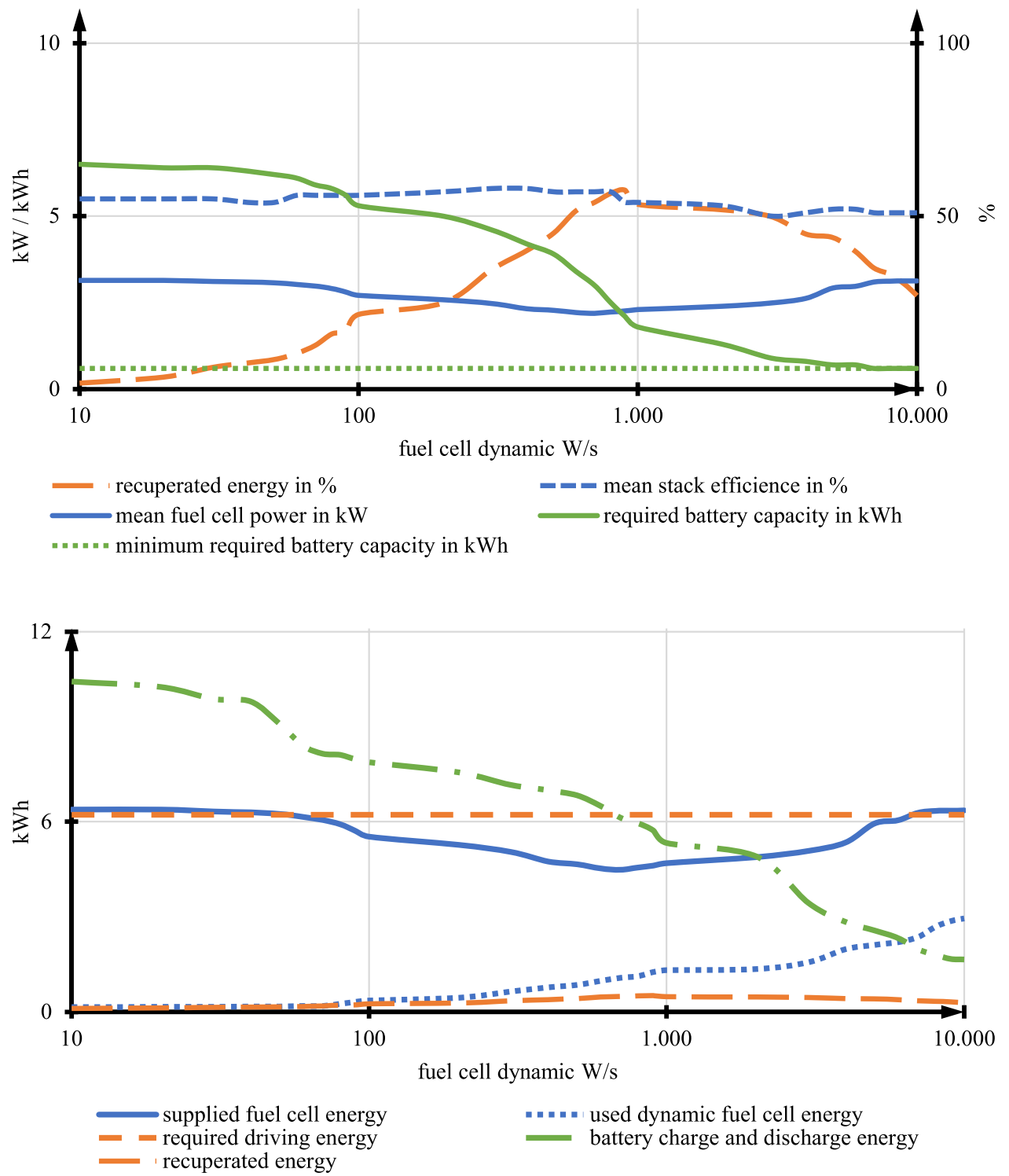

Fig. 5 Energy distribution in the WLTP without the use of a supercapacitor supercapacitor, hence the minimum battery capacity of 0.3 $\mathrm{kWh}$. Nevertheless, the fuel cell can follow the load change of the driving task with higher dynamics and requires this low battery capacity only due to a lag in dynamic response.

Figure 7 shows the energy distribution of the fuel cell vehicle. It can be seen that the capacity of the supercapacitor is fully needed regardless of the fuel cell dynamic and the battery. In addition, the provided fuel cell power adapts to the required driving performance as the dynamic increases. Furthermore, the charging and discharging energy of the battery is reduced. The dynamic fuel cell can independently meet the performance requirement of the driving task. Compared to the simulation without a supercapacitor, the supplied fuel cell power is lower. This is due to the additional buffer which reduces the dynamic requirement and thus the required power reserve. 
Fig. 6 Simulation result of the WLTP with supercapacitor
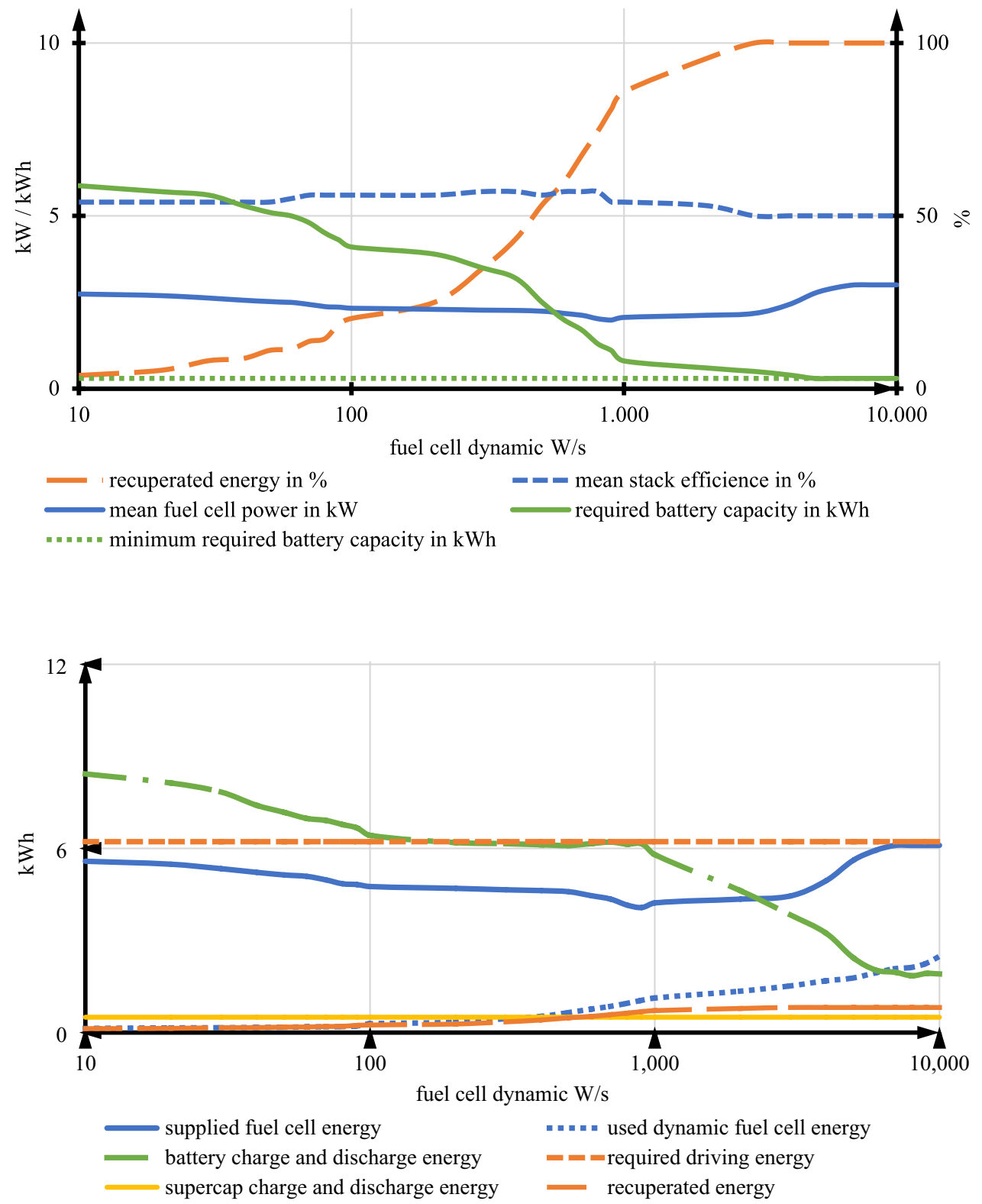

Figure 8 displays the results for the simulation with a sufficiently large supercapacitor with a constant capacity at $6.5 \mathrm{kWh}$. The capacity corresponds to the initial storage capacity of the battery. With the sole use of a supercapacitor, a battery not bot being required anymore. It can be seen that the efficiency of the fuel cell stack and the provided fuel cell power does not change. Also, the recuperation ability increases considerably to an average of $74.4 \%$ compared to the other energy storage variants. The recuperation ability behaves relatively independent of the fuel cells given dynamics. This behaviour is due to the high current tolerance of the supercapacitor and shows the considerable increase in efficiency of the drivetrain through the use of a supercapacitor instead of a battery.

\section{Conclusion and outlook}

Within the "Determination of the optimal battery capacity of a PEM fuel cell vehicle taking into account recuperation and supercapacitors", an FCEV was simulated. The influences of the interdependencies within the cell, the operating media management and the electric drive train were investigated. Furthermore, the dynamics of the fuel cell system were considered. The drive train, the energy storage battery and supercapacitor as well as their combination were researched for their recuperation potential.

It can be stated that the battery capacity of an FCEV can be reduced with the help of a supercapacitor. This is because 
Fig. 8 Simulation result of the WLTP with a larger supercapacitor

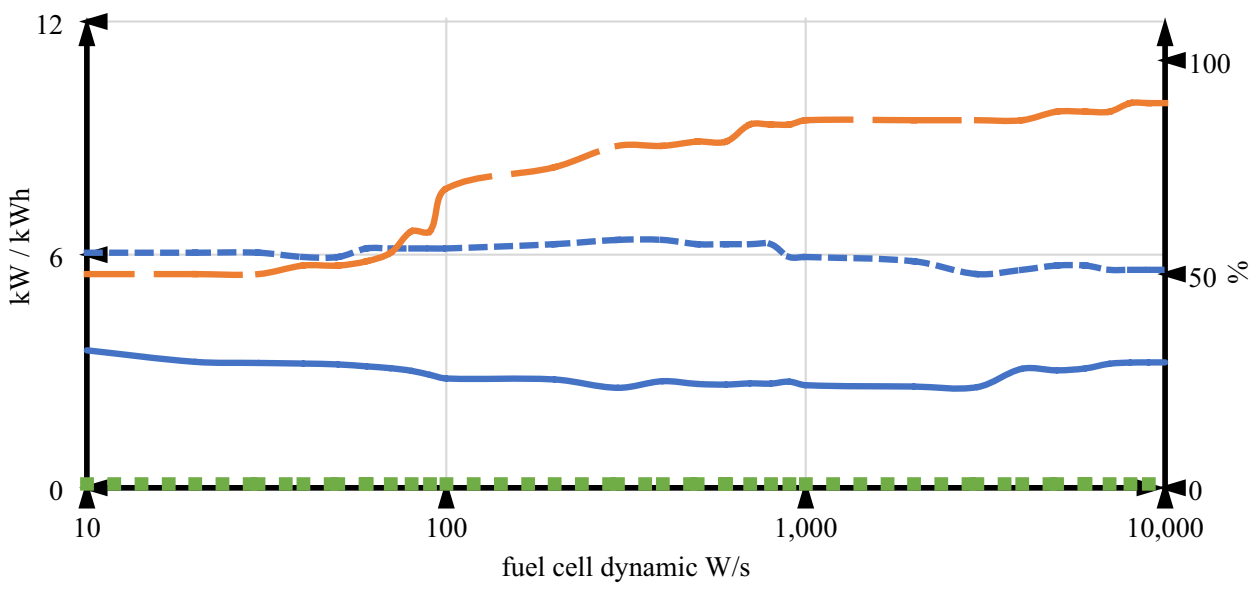

- mean stack efficience in \%

- recuperated energy in \%

required battery capacity in $\mathrm{kWh}$ a proportionally small-sized battery is not able to absorb all the energy generated by the fuel cell due to the charging limit of a C-Rate of 3 (peak smaller than $10 \mathrm{~s}$ : C-Rate of 5) in case of a load step. This can be seen in the reduced recuperation capacity of the drive train, which reaches the maximum value of $57.5 \%$. Even a higher dynamic of the fuel cell cannot compensate for this parameter limitation.

Based on the above, it can be said that from a certain value onwards, the dynamic system behaviour no longer affects the optimal battery capacity, regardless of supercapacitors use. This is due to the maintenance of power of the drive train, which is ensured by the battery. Also, in case of the 'WLTP', the calculations showed that the efficiency of the fuel cell has a continuous value separate of the system behaviour. Additional simulations have also shown that a large gap between the maximum power of the electric motor and the fuel cell stack has an influence on the optimal battery capacity of the vehicle leading to a higher required capacity.

The usage of a supercapacitor is of considerable relevance for the energy management of a fuel cell vehicle, as it can increase the recuperation capacity and ultimately the overall efficiency of the vehicle. It can be stated that with a sufficiently large supercapacitor, there is no need for a battery in the drive train. However, a battery must be kept available for conditioning the fuel cell, as a supercapacitor cannot ensure long-term maintenance of the state-of-charge.

As part of the optimal design of an FCEV, it will be necessary in the future to consider the use of the efficiency potentials by various energy storage systems and their combination for further realistic driving cycles.

The resulting requirements have to be transferred to the individual components of the FCEV, both at the overall vehicle level and at the level of the entire fuel cell system including the operating media management, such as the electric compressor. Also of particular interest will be to determine the optimal capacitance of a supercapacitor for PEM fuel cell vehicles.

Concluding, the generated simulation model of a PEM fuel cell vehicle can be used for the dimensioning of vehicles of different designs, taking into account the relevant factors like recuperation ability, battery and supercapacitor depending on the dynamics of the fuel cell system.

Supplementary Information The online version contains supplementary material available at https://doi.org/10.1007/s41104-021-00086-1.

Funding Open Access funding enabled and organized by Projekt DEAL. This research received no external funding.

Data availability Available under: https://1drv.ms/u/s!AhEJeZWS9x ZVgd8VcM1vAhyhdnmUKg?e=PJ4HYe

\section{Declarations}

Conflicts of interest The authors declare no conflict of interest.

Open Access This article is licensed under a Creative Commons Attribution 4.0 International License, which permits use, sharing, adaptation, distribution and reproduction in any medium or format, as long as you give appropriate credit to the original author(s) and the source, provide a link to the Creative Commons licence, and indicate if changes were made. The images or other third party material in this article are included in the article's Creative Commons licence, unless indicated otherwise in a credit line to the material. If material is not included in the article's Creative Commons licence and your intended use is not permitted by statutory regulation or exceeds the permitted use, you will need to obtain permission directly from the copyright holder. To view a copy of this licence, visit http://creativecommons.org/licenses/by/4.0/.

\section{References}

1. Kurzweil, P.: Brennstoffzellentechnik: Grundlagen, Materialien, Anwendungen, Gaserzeugung 3, überarbeitete und, aktualisierte Springer Fachmedien Wiesbaden GmbH, Wiesbaden (2016) 
2. Abd El Monem, A., Azmy, A., Mahmoud, S.: Effect of process parameters on the dynamic behavior of polymer electrolyte membrane fuel cells for electric vehicle applications. Ain. Shams. Eng. J. 5(1), 75-84 (2014). https://doi.org/10.1016/j.asej.2013.05.001

3. Scholta, J.: Dynamischer Betrieb von PEM-Brennstoffzellen. Available online https://www.zsw-bw.de/projekt/h2-und-brenn stoffzellen/dynamischer-betrieb-von-pem-brennstoffzellen.html. Accessed 27 July 2021

4. Sim, K., Vijayagopal, R., Kim, N., Rousseau, A.: Optimization of component sizing for a fuel cell-powered truck to minimize ownership cost. Energies 12(6), 1125 (2019). https://doi.org/10. 3990/3n12061125

5. Fletcher, T., Ebrahimi, K.: The effect of fuel cell and battery size on efficiency and cell lifetime for an L7e fuel cell hybrid vehicle. Energies 13(22), 5889 (2020). https://doi.org/10.3990/en132 25889

6. Rousseau, A., Sharer, P., Ahluwalia, R.: Energy storage requirements for fuel cell vehicles. Tech. Rep. (2004). https://doi.org/10. 4271/2004-01-1302

7. Schiffer J., Bohlen O., De Doncker R. W., Sauer D. U., Ahn K. Y.: Optimized energy management for fuelcell-supercap hybrid electric vehicles, 2005 IEEE Vehicle Power and Propulsion Conference. Chicago, IL, USA, pp. 341-348 (2005). https://doi.org/ 10.1109/VPPC.2005.1554637

8. Wurzenberger, J., Glatz, T., Rašić, D., Tavčar, G., Mele, I., Kregar, A., Katrašnik, T.: FCEV simulation-electrochemical battery and fuel cell models on vehicle level. In: Michael, B., Hans-Christian, R., Andreas, W. (eds.) 20. Internationales Stuttgarter Symposium, pp. 219-233. Springer Fachmedien Wiesbaden, Wiesbaden (2020)

9. Ettihier, K., Boulon, L., Agbossou, K., Kelouwani, S., Hammoudi, M.: Design of an energy management strategy for PEM Fuel Cell Vehicles. In: Industrial Electronics (ISIE) Conference, IEEE International Symposium, 2012

10. Hong, J., Jung, S.-Y., Thang, P., Nam, K.: Hybridization fuel cell with supercapacitor for FCEV. In: Applied Power Electronics Conference and Exposition, 2008. https://doi.org/10.1109/APEC. 2008.4522735
11. Thounthong, P., Chunkag, V., Sethakul, P., Davat, B., Hinaje, M.: Comparative study of fuel-cell vehicle hybridization with battery or supercapacitor storage device. IEEE. Trans. Veh. Technol. 58(8), 3892-3904 (2009). https://doi.org/10.1109/TVT.2009. 2028571

12. Schaltz, E., Khaligh, A., Rasmussen, P.: Influence of battery/ ultracapacitor energy-storage sizing on battery lifetime in a fuel cell hybrid electric vehicle. IEEE. Trans. Veh. Technol. 58(8), 3882-3891 (2009). https://doi.org/10.1109/TVT.2009.2027909

13. Hornburg, G.: Optimal interplay between fuel cell and battery: Mercedes-Benz GLC F-CELL. International Hydrogen Symposium, Hamburg (2019)

14. Lazar, A., Konradt, S., Rottengruber, H.: Open-source dynamic matlab/simulink 1d proton exchange membrane fuel cell model. Energies 12(18), 3478 (2019). https://doi.org/10.3990/en121 83478

15. Stadler, I., Sterner, M.: Energiespeicher, 2nd edn. Springer Vieweg, Wiesbaden (2017)

16. Hofmann, P.: Hybridfahrzeuge. Springer-Verlag, Wien (2014)

17. N, N.: Data sheet MCE0010C0-0090R0TBA. Supreme Power Solutions. Available online https://www.capcomp.de/fileadmin/ Webdata/partner/SPSCAP/Datasheet_module/Data-Sheet_ MCE0010C0-0090R0TBA-E.pdf. Accessed 27 July 2021

18. Borgeest, K.: Elektronik in der Fahrzeugtechnik: hardware, software, systeme und projektmanagement, 4th edn. Springer Fachmedien Wiesbaden $\mathrm{GmbH}$, Wiesbaden (2021)

19. Dorn, R., Schwartz, R., Steurich, B.: Batteriemanagementsystem. In: Korthauer, R. (ed.) Handbuch lithium-ionen-batterien, 1st edn., pp. 177-187. Springer Vieweg, Heidelberg (2013)

20. Tschöke, H., Gutzmer, P., Pfund, T.: Elektrifizierung des Antriebsstranges: Grundlagen-vom Mikro-Hybrid zum vollelektrischen Antrieb, 1st edn. Berlin Springer Vieweg, Heidelberg (2019)

Publisher's Note Springer Nature remains neutral with regard to jurisdictional claims in published maps and institutional affiliations. 